A sequential analysis has been performed on the data based upon the results from each group of pigs and the measurements made were mean growth rate and food conversion ratio during the prefattening period of 30 days.

Propericiazine $(0,5 \mathrm{mg} / \mathrm{kg}$ IM) was found to reduce growth rate when used after the short journey but increased growth rate and food conversion after the long journey when compared with controls injected with a placebo. The results indicate the usefulness of appropriately planned clinical trials.

\title{
MODIFICATIONS DANS LES RYTHMES D'ACTIVITÉ MOTRICE DES PORCELETS LORS DE L'ENTRÉE EN PORCHERIE
}

\author{
R. DANTZER \\ Station de Pharmacologie et de Toxicologie, I. N. R. A., \\ Saint-Martin du Touch, 180, Chemin de Tournefeuille, \\ 31300 Toulouse
}

\section{RÉSUMÉ}

La mesure de l'activité motrice de porcelets sevrés par un dispositif utilisant des cellules photoélectriques a permis de mettre en évidence l'existence d'un rythme nycthéméral caractérisé par 2 pics. le pic matinal était inférieur au pic vespéral. L'étude des variations de ce rythme au cours des 20 premiers jours de l'entrée en porcherie a été effectuée sur les paramètres suivants : l'importance de l'activité nocturne par rapport à l'activité quotidienne, le nombre total d'impulsions obtenu par jour; des indices de répartition de l'activité, calculés sur les percentiles 25 et 75 et la médiane, à partir de la courbe cumulative des pourcentages d'activité horaire. Les phénomènes d'adaptation se traduisent par une hyperactivité surtout manifeste pendant les trois premiers jours, une activité nocturne faible et un étalement de l'activité diurne dans le temps peu important. Le paramètre le plus sensible semble être représenté par l'indice relatif qui traduit la comparaison de la répartition de l'activité matinale à celle de l'activité vespérale et qui nécessite huit jours pour atteindre une valeur stable.

Ces résultats témoignent de l'importance et de l'intérêt d'une approche en termes de rythmes biologiques dans l'appréciation de la durée et de l'intensité des phénomènes d'adaptation chez le porc.

\section{SUMMARY}

\section{CHANGES IN LOCOMOTOR ACTIVITY OF WEANED PIGLETS AFTER MOVING IN A NEW PIGGERY}

Locomotor activity of weaned piglets has been studied using a photocell technique. A circadian rhythm was observed in which the main features were predominance of diurnal activity and existence of two peaks, $i . e$. a morning peak and a larger afternoon peak. Changes in 
this rhythm, after moving the animals to another piggery have been followed using the following parameters : amount of nocturnal activity, amount of diurnal activity, and also statistical indexes of the distribution of activity based on percentiles 25 and 75 and on the median from the cumulative curve of hourly activity percentages.

Adaptation to the new piggery is correlated with a decrease in daily activity and an increase in nocturnal activity. The most sensitive measurement seems to be the ratio of morning activity distribution to afternoon activity distribution and this index takes 8 days to stabilize.

These results indicate the usefulness of studying biological rhythms for the evaluation of adaptation to changes of environment in pigs.

\title{
ÉTUde DE QUELQUES PARAMÈTRES DE VARIATION DE LA COMPOSITION DES EFFLUENTS DE PORCHERIE
}

\author{
E. SALMON-LEGAGNEUR, J.-P. GAYRAL, J.M. LEVEAU et J. RETTAGLIATI \\ Station de Recherches sur l'Élcvage des Porcs, \\ Centre national de Recherches zootechniques, I. N.R. A., \\ 78350 Jouy en Josas
}

\section{RÉSUMÉ}

Les variations de la quantité et de la composition des effluents de porcs ont été déterminées en fonction du stade physiologique, de la composition de la ration et du mode d'élevage.

L'influence du stade physiologique a été déterminée chez des porcelets âgés de 4 à 7 semaines, des porcs en croissance de 30 à $100 \mathrm{~kg}$ et des truies en gestation et lactation. La $\mathrm{DBO}_{5}$ est proportionnelle au poids chez le porc en croissance tandis que la pollution émise (par unité de poids) est plus forte chez le porcelet et plus faible chez la truie gestante.

La composition de la ration a une faible influence, il apparaît cependant des variations des propriétés dues à l'augmentation du taux des différents constituants de la ration : lipides (augmentation de la $\mathrm{DBO}_{5}$ ), cellulose (augmentation de la $\mathrm{DCO}$ ), azote (augmentation de l'azote).

Le mode d'élevage (litière de paille et lavage de la porcherie) a une influence importante sur le volume, la matière sèche et la composition des fractions solide et liquide de l'effluent.

\section{SUMMARY}

\section{SOURCES OF VARIATIONS OF POLLUTION PARAMETERS IN PIG WASTES}

Influence of physiological stage, composition of diet and management on amount and composition of pig waste was assessed.

Influence of physiological stage has been determined from 4-7 weeks early weaned piglets, 